\title{
The feminization of the cooperative bank's board as a factor differentiating its financial performance
}

\author{
Rafał Balina; Marta Idasz-Balina \\ Department of Finance, Faculty of Economic Sciences, Warsaw University of Life \\ Sciences, Poland \\ e-mail correspondence: rafal_balina@sggw.pl
}

\begin{abstract}
The research was aimed at showing the relationship between the gender of the CEO and the efficiency of the Polish cooperative banks. The research covered 354 banks operating in Poland in 2013-2015. Based on the conducted research, it has been shown that, for the surveyed Polish cooperative banks, women served as CEOs in significantly smaller banks than men, as the number of clients, the number of members, the total value of assets and the value of equity in male-dominated banks was on average more than double. In banks managed by women. At the same time, the results of the research clearly showed that the gender of the person acting as the chairman of the management board in a cooperative bank had an impact on the level of its financial effectiveness.
\end{abstract}

Keywords: financial performance, cooperative bank, gender, management board, feminization ratio.

JEL classification: J71, J53

\section{INTRODUCTION}

Shaped over the centuries and still persisting division of roles for men and women meant that continues stereotype that male role is bound to activity outside the home, and the work of women within the household. Because individual types of activities require different traits and behavioral patterns, men are expected to be competitive, decisive and action oriented, while women are perceived to be involved exclusively in the sphere of domestic life (Budrowska, Duch i Tikow, 2003).

Attributes associated with femininity for a long time excluded or limited the possibility of entering the business world. This situation has gradually changed in recent years. The issue of differentiating statutory entities - in this case financial entities with regard to gender and the performance of said financial institutions has become relatively popular. One of the reasons for this attention is the widely considered observation regarding the low membership of women in the highest statutory corporate entities. In many countries around the world, the participation of women in high management positions in corporations continues to lag behind the numbers of men. Over the years this condition has incurred change as more women were appointed to management positions. This change has been a result of certain societal shifts which encouraged modifying women's status in the contemporary world. Additionally it also results from efforts made by various institutions to increase women's engagement in corporate management. Norway, as one of the first to declare by law, requires that corporate management be made to be at least 40\% women (Ahern i Dittmar, 2012). 
Similarly, Spain required an increase of women in management boards and management to a level at least $40 \%$ (Adams \& Ferreira, 2009). Sweden warned its business community that if corporate management was not at least $25 \%$ women, business would feel the legislative consequences. Following Norway, Spain and Sweden were other European states encouraging their business community to increase women's engagement in important management bodies. For example, Poland already has a "Code of Best Practices for WSE Listed Companies" (Karta Praw Podstawowych, 2007) which encourages raising women's presence in the statutory corporations. A similar mechanism was introduced by the Netherlands, France and Germany (Bøhren \& Strøm, 2010). These changes are introduced on the conviction that women's presence in corporate management will have a positive influence on management operations (Adams \& Ferreira, 2009). Others indicate that women's presence in key positions will lead to a better understanding of markets and clientele. They further indicate that corporations will also experience greater creativity and innovation. Smith points to the gains in efficient problem solving, and above all, points out that with women in management, the corporate image improves in the eyes of clientele and stakeholders (Smith, Smith i Verner, 2006).

Besides the benefits of women's participation in management, literature shows there is a detrimental aspect of this condition. Early and Mosakowski point out that one-gender bodies tend to communicate in straight-forward fashion and agree to a consensus more quickly - a most important quality when making decisions (Earley i Mosakowski, 2000). Furthermore, we can observe that 'male only' groups are more inclined to cooperation and less frequently suffer conflicts. Many studies show that balanced gender make-up of corporate bodies generate higher friction (Goodstein, Gautam i Boeker, 1994), extends decision making and significantly interferes with reaching compromise (Knight i inni, 1999), and probably induce into higher corporate costs. Lau and Murnighan show that mixed corporate bodies have a negative impact on performance - a result of procrastination during decision-making (Lau i Murnighan, 1998). Not less frequent are benefit/liability studies of women statutory corporate bodies and literature abounds with studies considering gender-varied management and boards of directors' impact on financial performance where contrasting voices find their venue. A number of studies point to a positive correlation gender-varied corporate management and financial performance. Erhardt determined that those American corporations where decision making is dominated by women show better ROA and ROI performance than those dominated by men (Erhardt, Werbel i Shrader, 2003). Campbell and Minguez-Vera confirmed the positive correlation between women's management membership and corporate performance measured Tobin's 'q' for corporations in Spain (Campbell i Mínguez-Vera, 2008). Mahadeo also demonstrated that women in corporate management positively influence return on assets (ROA) (Mahadeo, Soobaroyen i Oogarah-Hanuman, 2011). In Poland, Bohdanowicz among others, identified a correlation between gender-varied statutory entities and levels of ROA and ROE (Bohdanowicz, 2011). Other studies indicate a negative relation between women's participation in corporate management and the level of performance. For example, Aherni and Dittmar (2012), Böhren and Ström (2010), and Adams and Ferreira (2009), demonstrated a negative correlation between women in corporate management and Tobins ' $q$ ' indicator. Furthermore, Sharader also demonstrated a negative relation between women in American corporate management and levels of ROE, ROA, ROI and return on sales (ROS) (Shrader, Blackburn i Iles, 1997). Still other studies indicate absolutely no correlation between corporate performance and 
gender ratios in management, as in Randøy, Thomsen i Oxelheim (2006), Rose, (2007), Miller i Del Carmen Triana (2009).

What becomes apparent when reviewing the referred to international studies is differentiation with regard to sample size, country where the study is carried out, and the commercial activity of selected corporations. Noticeable is that there are few studies examining the financial sector - especially banks - which is a fundamental element of modern economies as confirmed by many studies (Owoputi, Kayode i Adeyefa, 2014). The strong connection between the banking sector and economy exists as well in Poland.

Poland's banking sector is divided into two categories - commercial and cooperative (co-op) where, because of its charter, co-op banks have an independent function in Poland's economy. Poland's co-op banks are an integral part of the banking sector as is confirmed from the Polish Financial Supervision Authority data: at the end of 2015, of 598 functioning banks. 560 were cooperative. More importantly, the total co-op banking sector possesses close to $8.5 \%$ of the total assets of Poland's banking sector, close to $7.5 \%$ of total borrowing, and close to $9.5 \%$ of total savings. Interestingly, Poland's co-op banks employ close to $20 \%$ of personnel working in the banking sector i.e. approximately 32.100 individuals working in 4.740 offices $-40 \%$ of all banking offices in Poland.

Another important element is that $80 \%$ of the co-op bank offices are located in smaller communities in rural and suburban areas. In result, the co-op banks are thus key players in commercial development in rural areas since commercial banks are little interested in these areas (Balina, 2015). Further, in many cases co-op banks counter tendencies of financial exclusion of less urbanized area residents. Nevertheless, co-op banks operate under a manifold theoretical basis and their identification requires examination of at least two aspects : first, they are cooperatives structured on the basis of a commercial interest; second, they are banks ergo credit institutions. This means that co-op banks are entities of a complex structure and the services they perform have significant impact on their behavior and activity. This complexity has influence on co-op banks' performance. An important condition that any co-op bank should fulfill is effective performance. For the bank to be effective, positive indicators and high profitability do not suffice; an effective co-op bank also accrues, over an extended period of time, assets and earned profits which should be properly exploited to insure the safety of its operation.

\section{METHODOLOGY}

The research involved the use of balanced panel data for the years 2013-2015 from 354 cooperative banks. The studied population of cooperative banks accounted for $62.7 \%$ of all cooperative banks operating in Poland as at December 31, 2016.

In order to determine the level of effectiveness of the cooperative banks in Poland the following measures of effectiveness were used: a) net financial result [WFN]; b) profitability ratio of own funds [ROE]; c) return on assets in total [ROA]; d) NPL indicator; e) TCR indicator.

The efficiency analysis was carried out within separate groups. The grouping was made based on the sex of the the president of the board and the feminization ratio of the management board of the cooperative bank, which was defined as the number of women sitting on the board of the cooperative bank to the total number of persons sitting on the board. Due to the significant diversity of banks in terms of the 
feminization rate, the analysis was conducted in the following groups: $0 \%, 1-25 \%$, $25-50 \%, 50-75 \%, 75-99 \%, 100 \%$.

\section{RESULTS}

The research was conducted on a group of 354 cooperative banks, of which 149 the president of the board were a woman and in the other 205 banks the man was the president. As can be seen from the data included in Table 1. Banks, whose function as the president of board were significantly larger - include the balance sheet total, total deposits, total loans and bank's own funds, than banks in which women performed this function. This indicates that men manage much larger banks than women.

Table 1. Characteristics of the research sample [thouseds of PLN]

\begin{tabular}{cccccc}
\hline Item & Total & Total & Total loans & Own Founds & Number of \\
\hline Female & 119937 & 102506 & 68793 & 13039 & 149 \\
Male & 206529 & 177799 & 126973 & 19677 & 205 \\
\hline Avrage & 170082 & 146108 & 102485 & 16883 & 354 \\
\hline
\end{tabular}

In addition, Figure 1 presents the relationship between the feminization ratio of the cooperative bank's board and its size. According to the analyzes carried out, the largest banks were banks in which the board was composed of men themselves (feminization rate equal to $0 \%$ ). Then co-operative banks were placed, in which women constituted from 75 to $99 \%$ of the total number of board members. Interestingly, the smallest banks in terms of adopted criteria were managed by women (the feminization rate equal to $100 \%$ ). What is equally interesting, the banks in which the functions of the board were performed by the women themselves were almost four times smaller than the banks in which the functions were performed by men themselves.

Subsequently, the relationship between the feminization ratio of the bank's board and the level of its effectiveness was estimated (Figure 2). According to the analyzes the net financial result of the banks surveyed was strongly correlated with the bank's size and feminization rate, as the highest net financial results were generated by banks with a feminization ratio of 0 , ie banks in which only managers were on the board. The lowest-value financial result was obtained by banks in which only women were members of the board (feminization rate equal to $100 \%$ ).

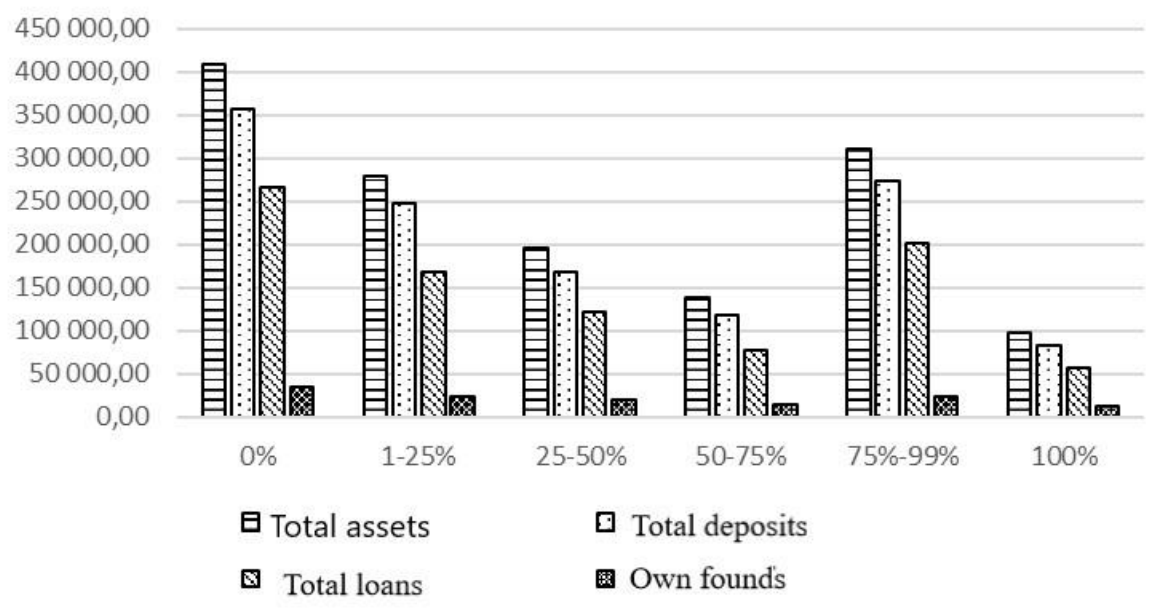

Figure 1. Relationship between the feminization coefficient of the cooperative bank's board and its size [data in thous. PLN] 
At the same time, taking into account the values of ROA and ROE, it was found that the differences were not as significant as in the case of the net financial result and the spread between the highest and the lowest result reached only 1.44 percentage points. No less noticeable is the tendency that along with the increase in the feminization rate of the board, co-operative banks obtained a lower level of ROE, outside the range between $75-99 \%$.

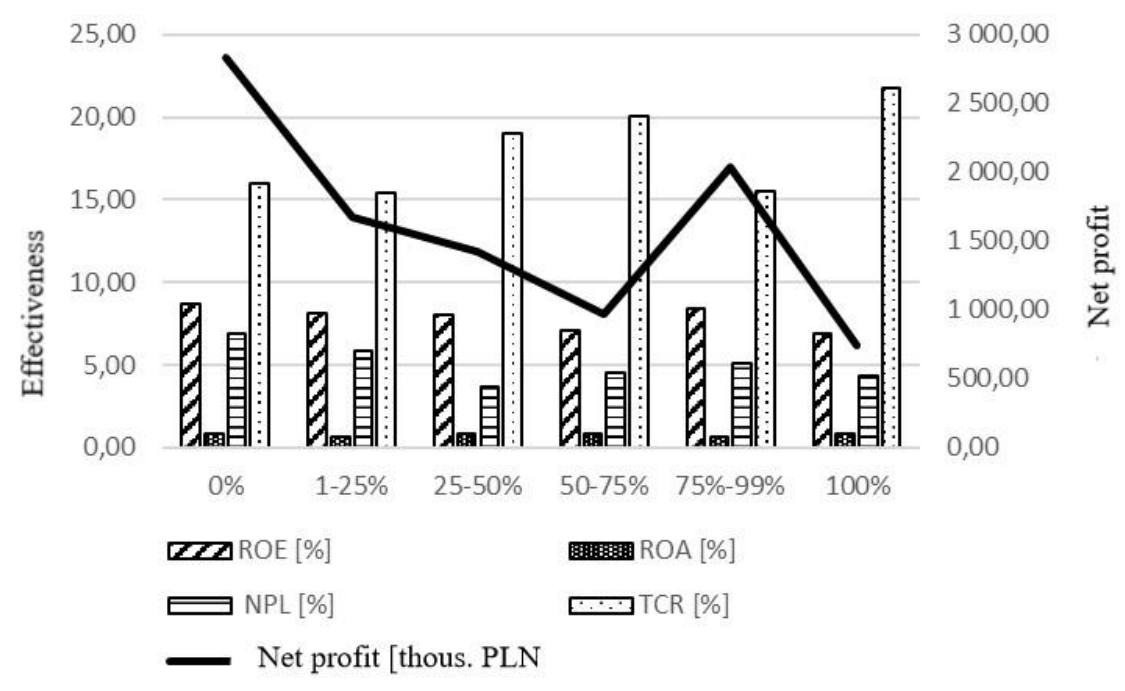

Figure 2. Relationship between the effectiveness of a cooperative bank and the feminisation rate of the board

In the case of the TCR index, the opposite tendency is noticeable, as the highest level of capital adequacy ratio was characterized by banks with a $100 \%$ feminization rate, and the lowest banks with $0 \%$ and $75-99 \%$ share of women on management boards. This may indicate that women are prone to lower risk. What results from the dependence that a higher solvency ratio (TCR) indicates a higher level of financial security of the bank, because the funds are considered able to cover a greater part of the risk generated by the bank. However, the higher the capital adequacy ratio, limits the bank's efficiency due to taking lower risk.

In the case of the relationship between the feminization rate and the NPL index determining the share of non-performing loans, i.e. loans with delays in repayment above 30, in the bank's loan obligation, there was no clear trend in this respect, which may indicate that both banks managed by women and by men are characterized by a similar level of credit risk.

Table 2 presents the relationship between the efficiency level of the cooperative banks studied and the feminization ratio of the board, depending on the sex of the president of the board. 
Table 2. Relationship between the effectiveness of the cooperative banks studied and the feminization ratio of the management board depending on the sex of the president of the board

\begin{tabular}{|c|c|c|c|c|c|c|c|c|c|c|}
\hline \multirow{2}{*}{ 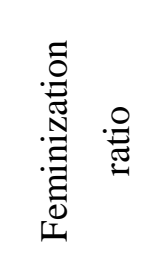 } & \multicolumn{2}{|c|}{$\begin{array}{l}\text { Wynik finansowy } \\
\text { netto [thous. PLN] }\end{array}$} & \multicolumn{2}{|c|}{ ROE [\%] } & \multicolumn{2}{|c|}{ ROA [\%] } & \multicolumn{2}{|c|}{ NPL [\%] } & \multicolumn{2}{|c|}{ TCR [\%] } \\
\hline & 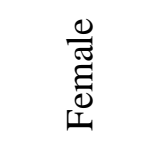 & $\frac{0}{N^{\pi}}$ & 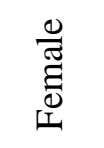 & $\frac{\frac{0}{\pi}}{\Sigma}$ & 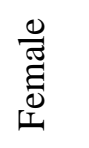 & $\frac{0}{\Sigma}$ & $\begin{array}{l}\frac{0}{\tilde{J}} \\
\tilde{\Xi} \\
\tilde{0} \\
\end{array}$ & $\frac{\frac{0}{J}}{\Sigma}$ & 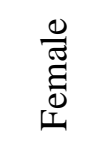 & $\frac{\frac{0}{\sigma}}{\Sigma}$ \\
\hline $1-25 \%$ & 4577 & & & & & 0 , & & $\sqrt{,}$ & 9 & 15 \\
\hline $25-50 \%$ & 887,28 & 149 & & & & 0,87 & 4,38 & 3,60 & 21,27 & 18,75 \\
\hline $50-75 \%$ & 929,01 & 995,76 & 7,41 & 6,90 & 0,85 & 0,75 & 3,48 & 5,35 & 20,85 & 19,50 \\
\hline $75 \%-99 \%$ & 1441,33 & 2232,89 & 9,87 & 7,88 & 0,99 & 0,57 & 2,80 & 5,84 & 15,07 & 15,61 \\
\hline
\end{tabular}

Interestingly, the conducted research clearly indicates that in the case of the efficiency of the bank's operation expressed in the net financial result, the highest level was characteristic for cooperative banks in which the woman was the chairman of the board and the remaining part of the board were men. Similar relationships are noticeable in the case of ROE. However, in the case of ROA, its highest level was recorded in the case of cooperative banks, in which women acted as the president of the board and the remaining part of the board were also women. Which may indicate that the efficiency of earned capital is the highest in banks in which only women are members of the board. Taking into account the level of risk undertaken by the surveyed banks, it was found that in the case of banks in which women accounted for $100 \%$ of the board, it was the lowest, which indicates a high level of financial security of the bank. In the case of banks managed mostly by men, the risk was significantly higher (see Table 2).

\section{CONCLUSIONS AND RECOMMENDATIONS}

\section{Conclusions}

On the basis of the conducted research, it was found that the size of cooperative banks managed solely by women was significantly lower than that of banks in which men were responsible for the management, which in the analysis of the net financial result translated into a lower level of efficiency of these entities. However, an in-depth analysis depending on the amount of the feminization rate showed that ROE is the highest in banks where only women are members of the board. The best effects also in terms of ROE were obtained for cooperative banks, where the feminization rate was relatively low, however, the woman was the president of the board and at the same time the supervisory role over the rest of the board members.

The research also showed that for TCR a tendency is noticeable, in which its highest level was characterized by banks with a $100 \%$ feminisation rate, and the lowest banks with a complete lack or marginal share of women on management boards. This may indicate that women are prone to lower risk and their actions are more conservative. What results from the dependence that a higher solvency ratio indicates a higher level of the bank's financial security, as the funds are considered able to cover a greater part of the risk generated by the bank. However, the higher solvency ratio may also cause the bank's efficiency to be reduced due to lower risk or lost profits. 


\section{Recomendations}

According to the analysis, it is not possible to give an unambiguous answer whether there are dependencies between the gender of the person holding the function of the president of the management board in the cooperative bank and the level of its effectiveness, however, the results obtained suggest that a woman in the role of the president of the management board may contribute to the financial efficiency of the cooperative bank.

\section{REFERENCES}

Adams, R. B., \& Ferreira, D. (2009, November). Women in the boardroom and their impact on governance and performance. Journal of Financial Economics, 94(2), pp. 291-309.

Adler, P. S. (2011). Market, Hierarchy, and Trust: The Knowledge Economy and the Future of Capitalism. Organization Science, 12(2), pp. 215-234.

Ahern, K. R. i Dittmar, A. K. (2012). The Changing of the Boards: The Impact on Firm Valuation of Mandated Female Board Representation. Quarterly Journal of Economics, 127(1), strony 137-197.

Balina, R. (2015, Februrary). Financial Services Costs in Poland's Cooperative Banking in Opinion of Small and Medium-size Enterprise. Management Studies, 3(1-2), strony 34-40.

Bohdanowicz, L. (2011). Zróżnicowanie organów statutowych pod względem płci a wyniki finansowe polskich spółek publicznych. Acta universitatis Nicolai Copernici Ekonomia XLII - nauki Humanistyczno-Społeczne, 402, strony 105-110.

Bøhren, Y., \& Strøm, Ø. R. (2010, November/December). Governance and Politics: Regulating Independence and Diversity in the Board Room. Journal of Business Finance \& Accouting, 37(9-10), pp. 1281-1308.

Budrowska, B., Duch, D. i Tikow, A. (2003). Szklany sufit: bariery i ograniczenia karier polskich kobiet. Raport z badań jakościowych. Warszawa: Instytut Spraw Publicznych.

Campbell, K. i Mínguez-Vera, A. (2008, December). Gender Diversity in the Boardroom and Firm Financial Performance. Journal of Business Ethics, 83(2), strony 435-451.

Earley, C. P. i Mosakowski, E. (2000). Creating Hybrid Team Cultures: An Empirical Test of Transnational Team Functioning. Academy of Management Journal, 43(1), strony 26-49.

Erhardt, N. L., Werbel, J. D. i Shrader, C. B. (2003, April). Board of Director Diversity and Firm Financial Performance. Corporate Governance: An International Review, 11(2), strony 102-111.

Goodstein, J., Gautam, K. i Boeker, W. (1994, March). The effects of board size and diversity on strategic change. Research Notes and Communication, 15(3), strony 241-250.

Holst, 1. i Schimeta, J. (2011). 29 von 906: Weiterhin kaum Frauen in Top-Gremien großer Unternehmen. DIW Wochenbericht, (strony 2-10). Berlin.

Karta Praw Podstawowych. (2007). Dz.U. C 303 z 14.12.2007, s.1, art. 23.

Knight, D., Pearce, C. L., Smith, K. G., Olian, J. D., Sims, H. P., Smith, K. A. i Flood, P. (1999). Top Management. Team Diversity, Group Process, and Strategic Consensus. Strategic Management Journal, 20, strony 445-465. 
Kochan, T., Bezrukova, K., Ely, R., Jackson, S., Joshi, A., Jehn, K., . . . Thomas, D. (2003, Spring). The Effects of Diversity on Business Performance: Report of the Diversity Research Network. Human Resource Management, 42(1), strony 3-21.

Kodeks Pracy,. (2010). art. 11(2), 11(3), 18(3a-3e).

Konstytucja RP,. (1997). art. 32 i 33.

Lau, D. C. i Murnighan, K. J. (1998, April). Demographic Diversity and Faultlines: The Compositional DYnamics of Organizational Groups. Academy of Management Review, 23(2), strony 325-340.

Lisowska, E. (2012). Kobiety w zarządach firm:różnorodność vs. patriarchalnyporządek. Ewa LisowskaKobiety w zarządach firm:różnorodność vs. patriarchalnyporządekKobieta i Biznes : akademicko-gospodarcze forum. 20/1-4, strony 12-21. Muzeum Historii Polski.

Mahadeo, J. D., Soobaroyen, T. i Oogarah-Hanuman, V. (2011, February). Board Composition and Financial Performance: Uncovering the Effects of Diversity in an Emerging Economy. ournal of Business Ethics, 105(3), strony 375-388.

Miller, T. i Del Carmen Triana, M. (2009, July). Demographic Diversity in the Boardroom: Mediators of the Board Diversity-Firm Performance Relationship. Journal of Management Studies, 46(5), strony 755-786.

Owoputi, J. ,., Kayode, O. F. i Adeyefa, F. A. (2014, September). Bank-specific, industry-specific and macroeconomic determinants of bank profitability in Nigeria. European Scientific Journal, 10(25), strony 408-423.

Randøy, T., Thomsen, S. i Oxelheim, L. (2006). A Nordic perspective on corporate board diversity. Oslo: Nordic Innovation Center.

Rose, C. (2007, March). Does Female Board Representation Influence Firm Performance? The Danish Evidence. Corporate Governance: An International Review, 15(2), strony 404-413.

Shrader, C. B., Blackburn, V. i Iles, P. (1997, Fall). Women In Management And Firm Financial Performance: An Exploratory Study. Journal of Managerial Issues, 9, str. 355.

Sifile, O., Suppiah, S. D., Muranda, Z. i Chavunduka, D. (2015). Women board members as a diversity tool for enhancing corporate governance and stakeholder value. European Journal of Business and Management, 7(11), strony 218-231.

Smith, N., Smith, V. i Verner, M. (2006). Do Women in Top Management Affect Firm Performance? A Panel Study of 2500 Danish Firms. International Journal of Productivity and Performance Management, 55(7), strony 569 - 593.

Terjesen, S., Sealy, R. i Singh, V. (2009, May). Women Directors on Corporate Boards: A Review and Research Agenda. Corporate governance: an international review, 17(3), strony 320-337.

Traktat o funkcjonowaniu Unii Europejskiej. (2004). Art. 8. 